\section{Growth and accumulation of carotenoids and nitrogen compounds in Gracilaria domingensis (Kütz.) Sonder ex Dickie (Gracilariales, Rhodophyta) cultured under different irradiance and nutrient levels}

\author{
Fernanda Ramlov, ${ }^{1}$ Jonatas M. C. Souza, ${ }^{1}$ André V. F. Faria, ${ }^{1}$ \\ Marcelo Maraschin, ${ }^{2}$ Paulo A. Horta, ${ }^{3}$ Nair S. Yokoya ${ }^{*}, 1$ \\ ${ }^{1}$ Núcleo de Pesquisa em Ficologia, Instituto de Botânica, Brazil, \\ ${ }^{2}$ Departamento de Fitotecnia, Centro de Ciências Agrárias, Universidade \\ Federal de Santa Catarina, Brazil, \\ ${ }^{3}$ Departamento de Botânica, Centro de Ciências Biológicas, Universidade \\ Federal de Santa Catarina, Brazil.
}

Revista Brasileira de Farmacognosia Brazilian Journal of Pharmacognosy 21(2): 255-261, Mar./Apr. 2011

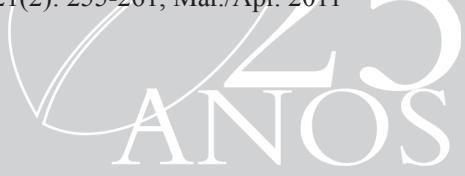

\begin{abstract}
Effects of the interaction of irradiance and nutrient levels on growth and contents of photosynthetic pigments, carotenoids and proteins in Gracilaria domingensis (Kütz.) Sonder ex Dickie (Gracilariales, Rhodophyta) were investigated experimentally. Nutrient availability provided by dilutions of the nutrient solution of von Stosch (25 and 50\%, which corresponded to nitrate concentrations of 125 and

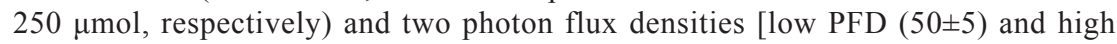
PFD $(100 \pm 5) \mu \mathrm{mol}$ photons $\mathrm{m}^{-2} \mathrm{~s}^{-1}$ ] were tested. Growth rates of $G$. domingensis were stimulated by high PFD. The interaction between high nutrient availability (50\% VSES) and high PFD stimulated the accumulation of total soluble protein. Phycobiliprotein concentrations (phycoerythrin, phycocyanin, and allophycocyanin) and carotenoid contents were influenced by irradiance levels. Phycobiliprotein concentrations were higher at low PFD and high irradiances stimulated carotenoid accumulation. These results reflect the function of these pigments in photoprotection and the acclimation of $G$. domingensis to changes in irradiance levels. Our results indicate that light is a limiting factor for $G$. domingensis growth, that variations in phycobiliprotein contents under different irradiance levels are related to photoacclimation process, and that higher carotenoid contents at high irradiances are due to a photoprotection mechanism.
\end{abstract}

\section{Article}

Received 3 Jan 2011

Accepted 25 Jan 2011 Available online 13 May 2011

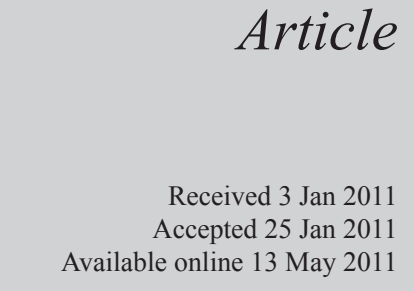

Keywords: carotenoids Gracilaria domingensis nutrients photon irradiances pigments proteins

ISSN 0102-695X doi: 10.1590/S0102-695X2011005000081

\section{Introduction}

Gracilaria domingensis (Kütz.) Sonder ex Dickie (Gracilariales, Rhodophyta) is a common species on the northeastern Brazilian coast, where it has been collected and exported to supply the Japanese food market (Plastino et al., 1999). In Brazil, several studies have been conducted with $G$. domingensis because of its colour polymorphism, which includes green, red and brown forms (Guimarães et al., 2003). The colour phenotype of $G$. domingensis obeys a simple Mendelian inheritance, with two nuclear co-dominant alleles (red and green) at one locus, while heterozygous tetrasporophytes have a brownish phenotype (Plastino et al., 1999). Moreover, the life history of this species is of the Polysiphonia-type (Guimarães et al., 1999). Since its cultivation is feasible on the northeastern and southern Brazilian coast, there is a growing interest in the study of its secondary metabolites as potential biologically active molecules. In addition, G. domingensis is also a potential source of dietary proteins, amino acids, lipids and essential fatty acids for humans and animals (Gressler et al., 2010).

Light and nutrient availability are factors that affect seaweed growth and these effects have also been reported for Gracilaria species (Wilson \& Critchley, 1997; Ursi \& Plastino, 2001; Kakita \& Kamishima, 2006; Ferreira et al., 2006). However, few reports have described the effect of these factors on the accumulation of pigments and proteins (Andria et al., 1999; Zou \& Gao, 2009). Denault et al. (2000) observed that concentrations of chlorophyll a and carotenoids increased with nitrogen concentration in Gracilaria tikvahiae McLachlan. Concentrations of carotenoids and phycobiliproteins are influenced by irradiances in Gracilaria species (Carnicas et al., 1999; Anderson 
et al., 2006) as photoprotection and photoacclimation responses.

The aims of the present work were to determine the effects of photon flux density and nutrient levels on growth rates and accumulation of proteins, photosynthetic pigments and carotenoids in Gracilaria domingensis.

\section{Materials and Methods}

Fertile female gametophytes of Gracilaria domingensis were collected from the intertidal region of Lagoinha Beach, Santa Catarina state, southern Brazil $\left(27^{\circ} 35^{\prime} \mathrm{S}\right.$ and $\left.48^{\circ} 33^{\prime} \mathrm{W}\right)$. Voucher specimens were deposited in the SP Herbarium at the Institute of Botany, São Paulo State, Brazil, under the accession number SP 400837. Unialgal cultures of tetrasporophytes were started from carpospore germination and cultured in sterilized seawater (salinity of $32 \pm 2$ PSU) enriched with $25 \%$ of von Stosch's solution (VSES medium), according to Edwards (1970), with a reduction of $50 \%$ in the concentration of vitamins. During the first month of carposporeling culture, germanium dioxide $\left(1 \mathrm{mg} \mathrm{L}^{-1}\right)$ was added to the medium. Cultures were incubated at $22 \pm 2{ }^{\circ} \mathrm{C}$ under a photon flux density (PFD) of $75 \pm 5 \mu \mathrm{mol}$ photons $\mathrm{m}^{-2} \mathrm{~s}^{-1}$, provided by cool-white fluorescent lamps with a 14:10 h light:dark cycle, without aeration. PFD was measured with a quantum photometer (LI-185, Li-Cor Inc., USA) equipped with an underwater quantum sensor (LI-193 SA, Li-Cor Inc., USA). Medium renewal was carried out every week.

\section{Experiments of irradiance and nutrient levels}

Apical segments of tetrasporophytes of Gracilaria domingensis isolated from unialgal cultures were used in the experiments. Two dilutions of the nutrient solution of von Stosch (25 and 50\%, which corresponded to nitrate concentrations of 125 and 250 $\mu$ mol, respectively) were tested under two photon flux densities [low irradiance $(50 \pm 5) \mu \mathrm{mol}$ photons $\mathrm{m}^{-2} \mathrm{~s}^{-1}$ and high irradiance $(100 \pm 5) \mu \mathrm{mol}$ photons $\mathrm{m}^{-2} \mathrm{~s}^{-1}$. Each treatment was performed in six replicates of six apical segments $(2 \mathrm{~cm})$ in each. These explants were cultured in Erlenmeyer flasks with $300 \mathrm{~mL}$ of culture medium. Other experimental conditions were the same as described for unialgal cultures.

Fresh biomass was recorded weekly at the same intervals as medium renewal. Growth rates were calculated as $\left[\ln \left(\mathrm{B}_{\mathrm{f}}-\mathrm{B}_{0} / \mathrm{T}_{\mathrm{f}}\right) \times 100 \%\right]$ (Brinkhuis, 1985), where $\mathrm{B}_{0}$ is the initial fresh biomass, $\mathrm{B}_{\mathrm{f}}$ is the final fresh biomass and $\mathrm{T}_{\mathrm{f}}$ corresponds to the experimental period (28 days).

\section{Carotenoid analyses}

Carotenoids were extracted from samples (1.0 $\mathrm{g}$ fresh mass, $\mathrm{n}=3)$ using hexane:acetone (1:1, $\mathrm{v} / \mathrm{v})$ containing $100 \mathrm{mg} \mathrm{L}^{-1}$ tert-butyl hydroxytoluene (BHT). Solutions were filtered through a cellulose membrane to remove particles and the organosolvent extract was evaporated under a $\mathrm{N}_{2}$ flux. The residue was dissolved in hexane $(3 \mathrm{~mL})$. Prior to chromatographic analysis, in $1 \mathrm{~mL}$ of the organosolvent extract was added $10 \% \mathrm{KOH}$ in methanol $(100 \mu \mathrm{L} / \mathrm{mL})$ in order to obtain complete carotenoid saponification, which allowed better identification of each compound by HPLC. This solution was incubated $(3 \mathrm{~h}$ in the dark at room temperature), followed by washing with distilleddeionized water (three times). The de-esterified extract was collected, concentrated under a $\mathrm{N}_{2}$ flux and resolubilized in hexane:acetone:BHT $(100 \mu \mathrm{L})$ for further chromatographic analysis, as previously described (Kuhnen et al., 2009). A concentrated sample $(10 \mu \mathrm{L}, \mathrm{n}=3)$ was injected onto the liquid chromatograph (Shimadzu LC-10A) equipped with a $\mathrm{C}_{18}$ reverse-phase column (Vydac 218TP54; $250 \mathrm{~mm}$ x $4.6 \mathrm{~mm} \varnothing, 5 \mu \mathrm{m}$, $30{ }^{\circ} \mathrm{C}$ ), protected by a $5 \mu \mathrm{m} \mathrm{C}_{18}$ reverse-phase guard column (Vydac 218GK54), and an UV-visible detector $(450 \mathrm{~nm})$. Elution was performed with $\mathrm{MeOH}: \mathrm{CH}_{3} \mathrm{CN}$ $(90: 10, \mathrm{v} / \mathrm{v})$ at a flow rate of $1 \mathrm{~mL} \cdot \mathrm{min}^{-1}$. Carotenoid identification $(\alpha$-carotene, $\beta$-carotene, lutein, zeaxanthin, and $\beta$-cryptoxanthin) was performed using retention times and co-chromatography of standard compounds (Sigma-Aldrich, St. Louis, MO, USA), as well as by analogy with other reports of carotenoid analysis by RP-HPLC-UV-visible under similar conditions (Scott \& Eldridge, 2005; Hulshof et al., 2007). Carotenoid quantification was based on standard curves, employing the lutein standard curve $(0.5-45$ $\left.\mu \mathrm{g} \mathrm{mL} L^{-1} ; y=7044 x ; r^{2}=0.999\right)$ for lutein, zeaxanthin and $\beta$-cryptoxanthin quantification and the $\beta$-carotene standard curve $\left(0.01-12 \mu \mathrm{g} \mathrm{mL}^{-1} ; \mathrm{y}=1019 \mathrm{x} ; \mathrm{r} 2=0.998\right)$ for $\alpha$ - and $\beta$-carotene quantification.

\section{Analyses of photosynthetic pigments and total soluble proteins}

Pigment extractions were carried out at $4{ }^{\circ} \mathrm{C}$ and samples ( $75 \mathrm{mg}$ of fresh mass, $\mathrm{n}=3$ ) were ground to a powder with liquid nitrogen and mixed with 50 $\mathrm{mM}$ phosphate buffer ( $\mathrm{pH}$ 5.5). The homogenates were centrifuged at $14000 \mathrm{rpm}$ for $20 \mathrm{~min}$ for separation of the phycobiliproteins present in the supernatants. Chlorophyll $a$ was extracted after dissolving the pellet in $90 \%$ acetone and centrifuging at $10000 \mathrm{rpm}$ for 15 min. Pigments were quantified by spectrophotometry (Shimadzu-UV 1800) and concentrations were calculated according to Kursar et al. (1983) for phycobiliproteins and Jeffrey \& Humphrey (1975) for chlorophyll $a$. 
For total soluble protein analyses, the algal biomass ( $75 \mathrm{mg}, \mathrm{n}=3$ ) was ground with liquid nitrogen, and extractions were carried out at $4{ }^{\circ} \mathrm{C}$ using $0.2 \mathrm{M}$ phosphate buffer (pH 8.0) containing 5 mM EDTA and $1 \mathrm{mM}$ DTT. Buffer was added in the ratio of $10 \mathrm{ml} \mathrm{g}^{-1}$ fresh biomass and the homogenates were centrifuged at $12000 \mathrm{rpm}$ for $15 \mathrm{~min}$. Total soluble protein contents were determined according to Bradford (1976), using a Bio-Rad protein assay kit and BSA as standard.

\section{Data analysis}

Data were analyzed by bifactorial Analysis of Variance (ANOVA) and the Student-Newman-Keuls' test (Zar, 1999). All statistical analyses were performed using the Statistica software package (Release 6.0), considering $p \leq 0.05$. Homogeneity of the variance was tested using Levene's test.

\section{Results}

Effects of the interaction of PFD and VSES concentration on the growth rates of tetrasporophytes of Gracilaria domingensis were not significant, while high PFD stimulated the growth (Figure 1, Table 1).

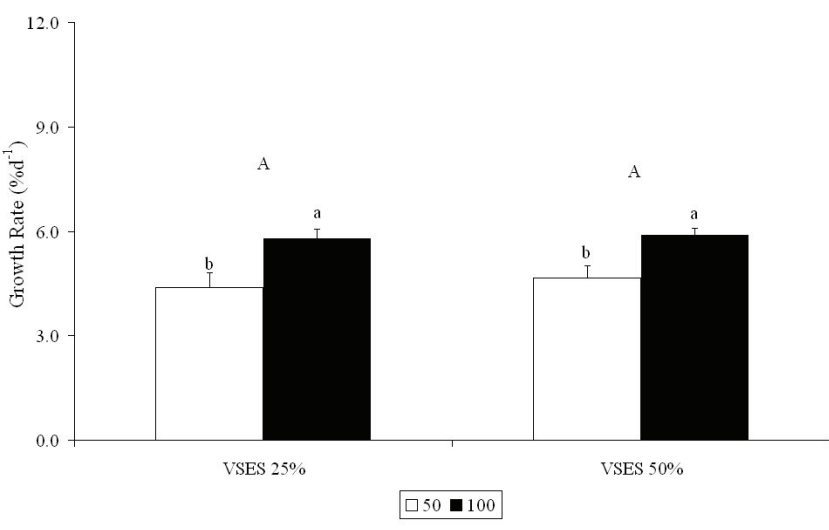

Figure 1. Growth rates (\% d-1) of apical segments of tetrasporophytes of Gracilaria domingensis cultured in von Stosch medium (25\% and 50\% VSES) under 50 (white bars) and 100 (black bars) $\mu \mathrm{mol}$ photons $\mathrm{m}^{-2} \mathrm{~s}^{-1}$ for four weeks. Values are averages $\pm \operatorname{SD}(n=6)$, with six segments of $2 \mathrm{~cm}$ per replicate. Different letters indicate significant differences according to the Student-Newman-Keuls' test $(p \leq 0.05)$. Capital letters indicate significant differences between VSES concentrations and lower case letters indicate differences between irradiance levels.

An interaction between PDF and VSES concentration stimulated protein accumulation and tetrasporophytes cultured in 50\% VSES under high PFD showed the highest protein concentration (Figure 2, Table 2).
Table 1. Two-away ANOVA of percentages of growth rates of tetrasporophytes of Gracilaria domingensis cultured in von Stosch medium (25 and 50\% VSES) under photon flux densities (PFD) of 50 and $100 \mu \mathrm{mol}$ photons $\mathrm{m}^{-2} \mathrm{~s}^{-1}$ for four weeks.

\begin{tabular}{cccc}
\hline Variable & df & $F$ & $p$ \\
\hline VSES & 1 & 1.604 & 0.219952 \\
PFD & 1 & 99.347 & 0.000000 \\
VSES x PFD & 1 & 0.469 & 0.501380 \\
\hline
\end{tabular}

Phycobiliprotein contents were not influenced by the interaction between PFD and VSES concentration (Table 3). However, PFD stimulated phycobiliprotein accumulation, with the highest concentrations of phycoerythrin, phycocyanin and allophycocyanin being present at low PFD (Figure 3, Table 3). The chlorophyll concentration was not affected by PFD and VSES concentration (Figure 3, Table 3).

Carotenoid composition (lutein, zeaxanthin, $\beta$-cryptoxanthin and trans- $\beta$-carotene) showed a variation, which was influenced by the culture conditions of the tetrasporophytes. Figure 4 shows a

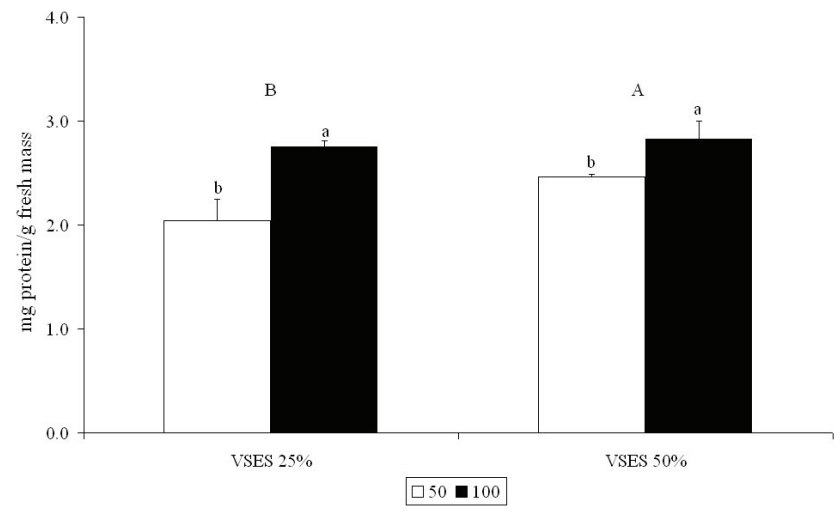

Figure 2. Total soluble protein content in apical segments of tetrasporophytes of Gracilaria domingensis cultured in von Stosch medium (25\% and 50\% VSES) under 50 (white bars) and 100 (black bars) $\mu \mathrm{mol}$ photons $\mathrm{m}^{-2} \mathrm{~s}^{-1}$ for four weeks. Values are averages $\pm \mathrm{SD}(\mathrm{n}=3)$, with six segments of $2 \mathrm{~cm}$ per replicate. Different letters indicate significant differences according to the Student-Newman-Keuls' test $(p \leq 0.05)$. Capital letters indicate significant differences between VSES concentrations and lower case letters indicate differences between irradiance levels.

Table 2. Two-away ANOVA of total soluble protein content of tetrasporophytes of Gracilaria domingensis cultured in von Stosch medium (25 and 50\% VSES) under photon flux densities (PFD) of 50 and $100 \mu \mathrm{mol}$ photons $\mathrm{m}^{-2} \mathrm{~s}^{-1}$ for four weeks.

\begin{tabular}{cccc}
\hline Variable & df & $F$ & $p$ \\
\hline VSES & 1 & 9.543 & 0.014 \\
PFD & 1 & 44.622 & 0.0001 \\
VSES x PFD & 1 & 4.684 & 0.062 \\
\hline
\end{tabular}


typical HPLC profile for the carotenoids.

The interaction between PFD and VSES concentration did not affect lutein and trans- $\beta$-carotene concentrations (Table 4). Concentrations of both compounds were only influenced by PFD, with the highest concentrations detected at high photon flux density (Figure 5A, E, Table 4). Free zeaxanthin and $\beta$-cryptoxanthin concentrations were influenced by the interaction between PFD and VSES concentration (Table 4 ), while treatment with low nutrient concentrations
(25\% VSES) under high PFD stimulated the highest accumlation of free zeaxanthin (Figure 5B) and high nutrient concentrations (50\% VSES) under high PFD stimulated the highest $\beta$-cryptoxanthin concentration (Figure 5D). For tetrasporophytes cultured under low PFD, the areas of the esterified zeaxanthin peaks were too small to allow quantification. At high PFD, the esterified zeaxanthin concentrations were the highest at low nutrient concentrations (25\% VSES, Figure 5C).
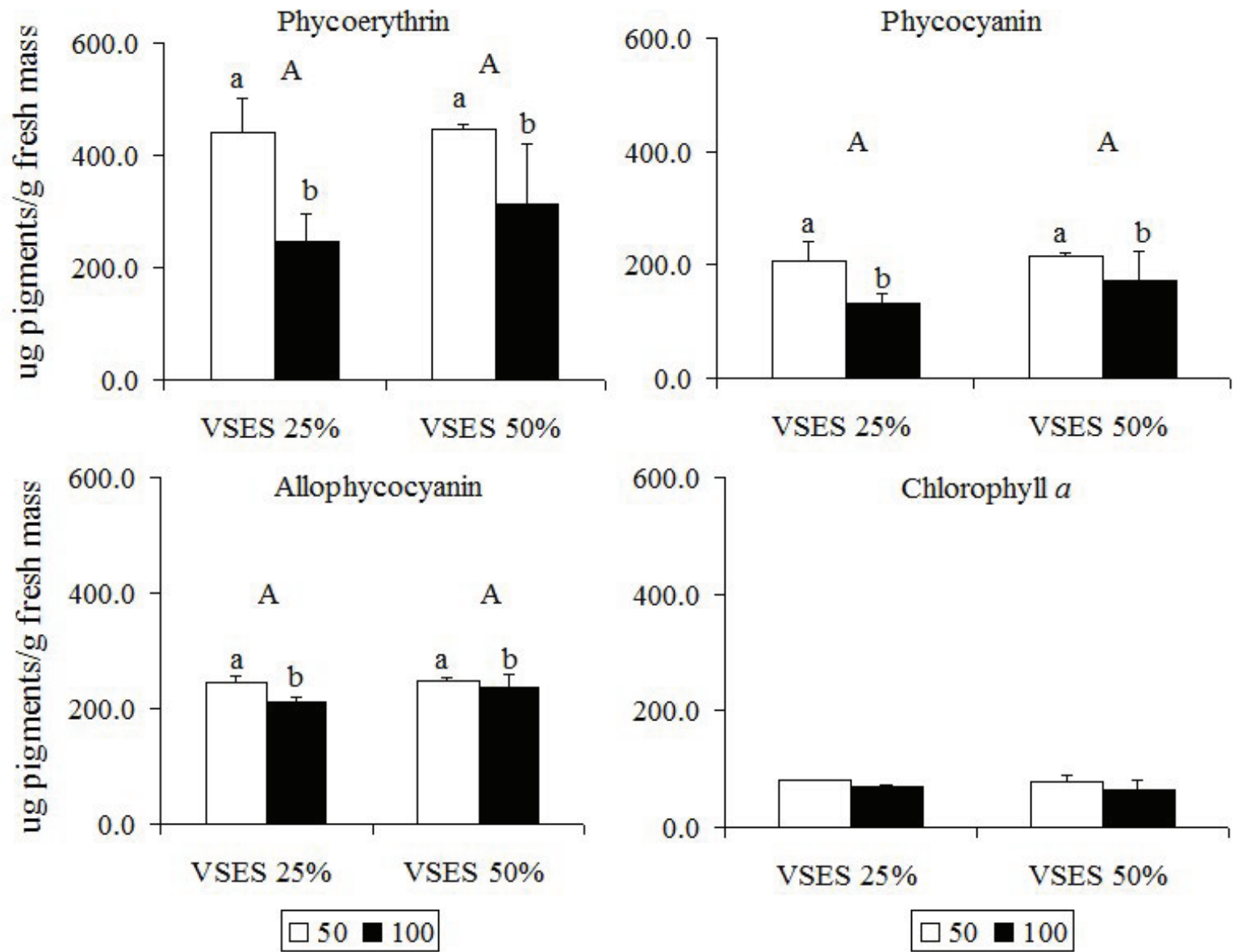

Figure 3. Photosynthetic pigment concentrations in apical segments of tetrasporophytes of Gracilaria domingensis cultured in von Stosch medium ( $25 \%$ and 50\% VSES) under 50 (white bars) and 100 (black bars) $\mu$ mol photons $\mathrm{m}^{-2} \mathrm{~s}^{-1}$ for four weeks. Values are averages $\pm \mathrm{SD}(\mathrm{n}=3)$, with six segments of $2 \mathrm{~cm}$ per replicate. Different letters indicate significant differences according to the Student-Newman-Keuls' test $(p \leq 0.05)$. Capital letters indicate significant differences between VSES concentrations and lower case letters indicate differences between irradiance levels.

Table 3. Two-away ANOVA of photosynthetic pigment concentrations of tetrasporophytes of Gracilaria domingensis cultured in von Stosch medium (25 and 50\% VSES) under photon flux densities (PFD) of 50 and $100 \mu \mathrm{mol}$ photons $\mathrm{m}^{-2} \mathrm{~s}^{-1}$ for four weeks.

\begin{tabular}{ccccccccccc}
\hline \multirow{2}{*}{ Variable } & \multirow{2}{*}{ df } & \multicolumn{2}{c}{ Phycoerythrin } & \multicolumn{2}{c}{ Phycocyanin } & \multicolumn{2}{c}{ Allophycocyanin } & \multicolumn{2}{c}{ Chlorophyll $a$} \\
\cline { 3 - 9 } & & $F$ & $p$ & $F$ & $p$ & $F$ & $p$ & $F$ & 0.201 \\
\hline VSES & 1 & 0.905 & 0.369 & 1.699 & 0.228 & 2.993 & 0.121 & 0.665 \\
PFD & 1 & 18.196 & 0.002 & 10.214 & 0.012 & 8.038 & 0.021 & 4.921 & 0.0573 \\
VSES x PFD & 1 & 0.684 & 0.431 & 0.769 & 0.405 & 1.792 & 0.217 & 0.057 & 0.816 \\
\hline
\end{tabular}




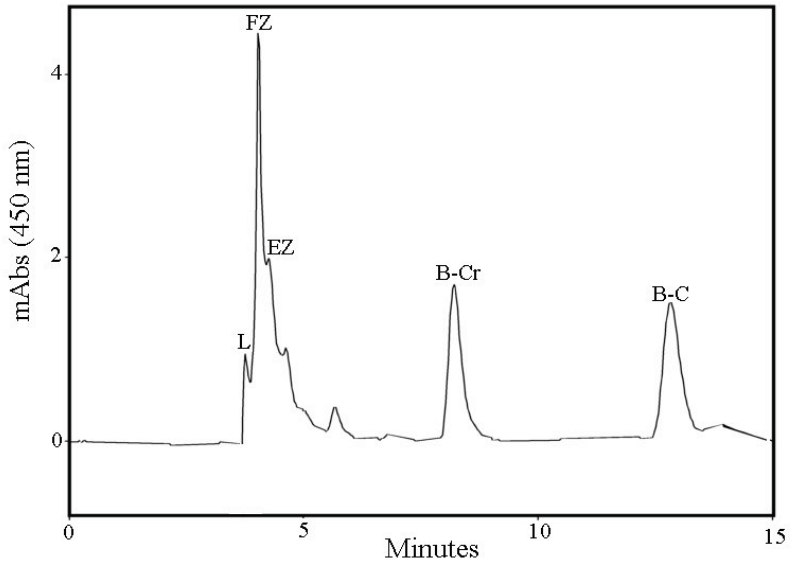

Figure 4. HPLC chromatogram for carotenoids detected in tetrasporophytes of Gracilaria domingensis cultured in $25 \%$ VSES under $100 \mu \mathrm{mol}$ photons $\mathrm{m}^{-2} \mathrm{~s}^{-1}$. Detection wavelength $450 \mathrm{~nm}$. L, lutein; FZ, free zeaxanthin; EZ, esterified zeaxanthin; $\beta$-Cr, $\beta$-cryptoxanthin; $\beta$-C, trans- $\beta$-carotene.

\section{Discussion}

Irradiance was a limiting factor for growth of $G$. domingensis and the highest growth rate was observed at high PFD. G. domingensis is found in the intertidal region and it is exposed to high irradiances. Moreover, growth of $G$. domingensis was not influenced by nutrient concentrations. Similarly, growth rates of G. foliffera var. angustissima (Harv.) Taylor (Lapointe, 1981) were not influenced significantly by an increase in nitrate concentrations.

Light (PFD) influenced phycobiliprotein concentrations in Gracilaria domingensis. The highest concentrations of phycoerythrin, phycocyanin and allophycocyanin were observed in tetrasporophytes cultured at low PFD. Similar results have also been reported for other Gracilaria species (Zou \& Gao, 2009) and could be related to a photoacclimation process at low irradiance. Concentrations of chlorophyll a in $G$. domingensis were not influenced by irradiance and nutrient levels and were lower than the phycobiliprotein contents.
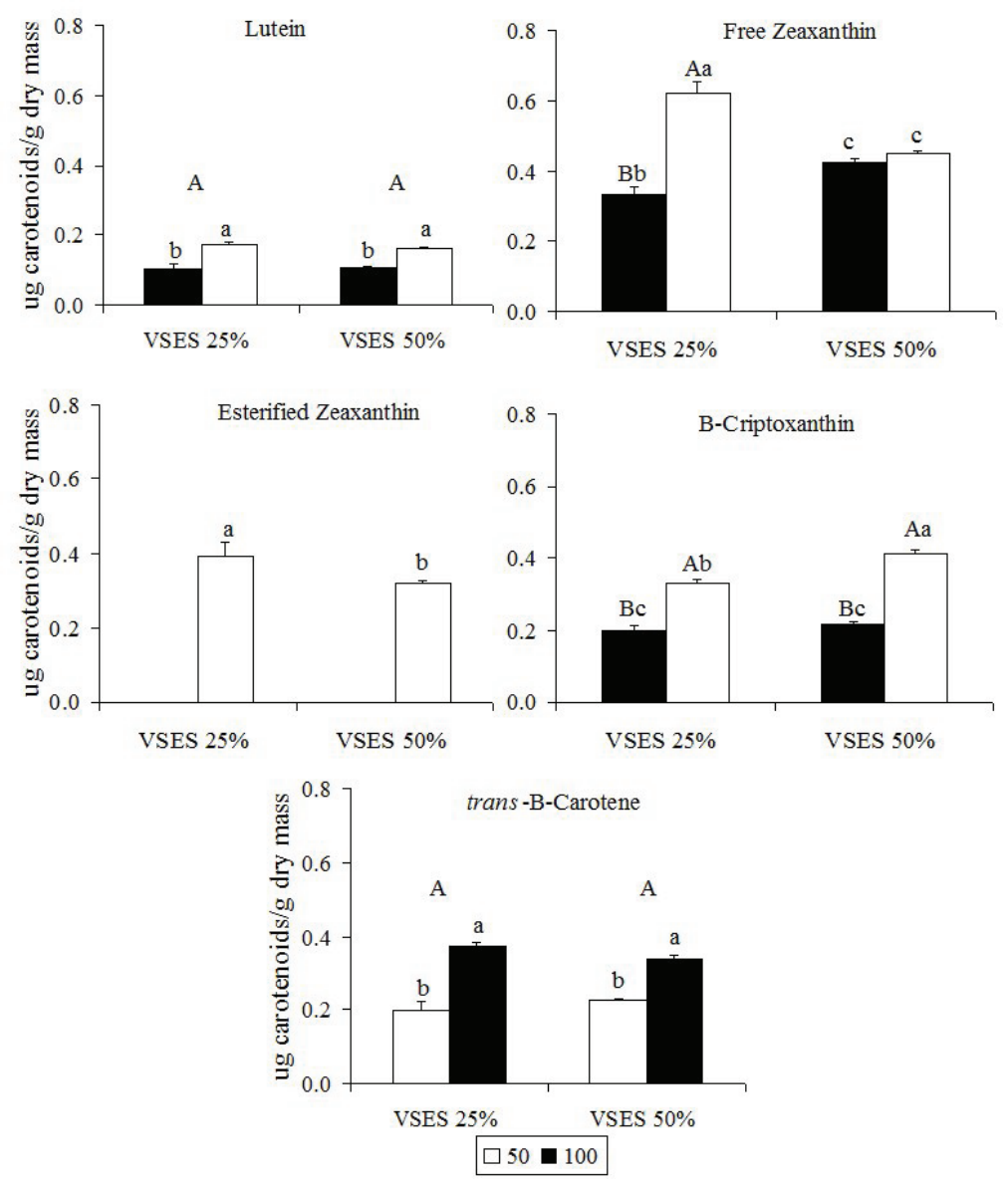

Figure 5. Carotenoid concentrations in apical segments of tetrasporophytes of Gracilaria domingensis cultured in von Stosch medium (25\% and 50\% VSES) under 50 (white bars) and 100 (black bars) $\mu$ mol photons $\mathrm{m}^{-2} \mathrm{~s}^{-1}$ for four weeks. Values are averages $\pm S D(n=6)$, with six segments of $2 \mathrm{~cm}$ per replicate. Different letters indicate significant differences according to the Student-Newman-Keuls' test $(p \leq 0.05)$. Capital letters indicate significant differences between VSES concentrations, and lower case letters indicate differences between irradiance levels. 
Table 4. Two-away ANOVA of carotenoid concentrations of tetrasporophytes of Gracilaria domingensis cultured in von Stosch medium (25 and 50\% VSES) under photon flux densities (PFD) of 50 and $100 \mu \mathrm{mol}$ photons $\mathrm{m}^{-2} \mathrm{~s}^{-1}$ for four weeks.

\begin{tabular}{ccccccccccc}
\hline \multirow{2}{*}{ Variable } & \multirow{2}{*}{ df } & \multicolumn{2}{c}{ Lutein } & \multicolumn{2}{c}{ Free zeaxanthin } & \multicolumn{2}{c}{$\beta$-criptoxanthin } & \multicolumn{2}{c}{$\beta$-carotene } \\
\cline { 3 - 10 } & & $F$ & $p$ & $F$ & $p$ & $F$ & $p$ & $F$ & 0.343 \\
\hline VSES & 1 & 2.742 & 0.136 & 8.565 & 0.022 & 62.623 & 0.000047 & 0.574 \\
PFD & 1 & 327.370 & 0.000 & 135.584 & 0.000008 & 643.148 & 0.000 & 357.044 & 0.000 \\
VSES x PFD & 1 & 2.379 & 0.161 & 95.728 & 0.000025 & 23.570 & 0.001 & 14.722 & 0.225 \\
\hline
\end{tabular}

The relationship between pigment content and nutrient availability has been investigated in several studies (Jones et al., 1996; Godillo et al., 2006), indicating that Gracilaria species are able to assimilate nitrogen and, when present in excess, nitrogen is stored as proteins or pigments (Kosovel \& Talarico, 1979). However, this is not the only factor determining the pigment concentrations. Light plays a key role and exerts an effect opposite to that of nitrogen (Talarico \& Maranzana, 2000), as observed in our results. According to Lapointe (1981), the interaction between these two factors affects the pigment concentrations and increases or decreases in these concentrations are related to the photosynthetic capacity.

Accumulation of total soluble protein was influenced by the interaction between PFD and nutrient availability. The highest protein concentration was observed at high nutrient concentration (50\% VSES) under high PFD. As discussed previously, Gracilaria species have the capacity to store nitrogen during periods of high nitrogen availability. Under optimal conditions for photosynthesis, there is no need to store nitrogen as phycobiliproteins and $G$. domingensis tetrasporophytes then store the excess nitrogen preferentially in the form of proteins. Andria et al. (1999) observed that the total soluble protein content of Gracilaria sp. decreased when the species was cultured under conditions of limited availabilityof nitrogen.

High levels of irradiance stimulated carotenoid accumulation in $G$. domingensis tetrasporophytes. Carotenoid concentrations were lower than phycobiliprotein concentrations, reflecting the carotenoid function of protecting the photosynthetic apparatus. Our results show that the $\beta$-carotene pathway was more active, since the concentrations of zeaxanthin, $\beta$-cryptoxanthin and $\beta$-carotene were higher than that of lutein. According to Demming-Adams (1990), zeaxanthin is a key pigment involved in the photoprotective response to the stress caused by high irradiance, because xanthophyll is more efficient at dissipating the excess energy (Frank et al., 2001). The high content of zeaxanthin during the acclimation to high irradiances suggests a response to the stress caused by excess light in $G$. domingensis. In a similar experiment, Carnicas et al. (1999) also observed an increase in zeaxanthin concentrations with increasing irradiance in G. tenuistipitata var. liui Zhang \& B.M. Xia.
The decrease in concentration of free zeaxanthin in $G$. domingensis cultured under conditions of low nutrient availability (25\% VSES) and low PFD and the reduction in $\beta$-cryptoxanthin concentration under low nutrient availability (25\% VSES) and high PFD could be a photoacclimation response to low nutrient availability.

In conclusion, our results indicate that light is a limiting factor for $G$. domingensis growth, that variations in phycobiliprotein contents under different irradiance levels are related to photoacclimation process, and that higher carotenoid contents at high irradiances are due to photoprotection mechanism.

\section{Acknowledgments}

The authors thank the Conselho Nacional de Desenvolvimento Científico e Tecnológico (CNPq, Brazil) for grants (Proc. 485927/07-1) and fellowships (Proc. $381175 / 2007-3,382175 / 2008-5,140824 / 2009-0)$ to the first author. This study is part of the thesis presented by the first author to the Graduate Programme in Plant Biodiversity and Environment, Institute of Botany, São Paulo, Brazil.

\section{References}

Andersson M, Schubert H, Pedersén M, Snoeijs P 2006. Different patterns of carotenoid composition and photosynthesis acclimation in two tropical red algae. Mar Biol 149: 653665.

Andria JR, Vergara JJ, Perez-Llorens JL 1999. Biochemical responses and photosynthetic performance of Gracilaria sp. (Rhodophyta) from Cádiz, Spain, cultured under different inorganic carbon and nitrogen levels. Eur $J$ Phycol 34: 497-504.

Bradford MM 1976. A rapid and sensitive method for the quantitation of microgram quantities of protein utilizing the principle of protein-dye binding. Anal Biochem 72: 248-254.

Brinkhuis BH 1985. Growth patterns and rates. In Littler MM, Littler DS (eds.) Handbook of Phycological Methods. London: Cambridge University Press, p. 461-478.

Carnicas E, Jimenez C, Niell FX 1999. Effects of changes of irradiance on the pigment composition of Gracilaria tenuistipitata var. liui Zhang et Xia. J Photoch Photobiol 50: 149-158.

Demming-Adams B 1990. Carotenoids and photoprotection in plants: a role for the xanthophyll zeaxanthin. Biochim 
Biophys Acta 1020: 1-24.

Denault M, Stieve E, Valiela I 2000. Effects of nitrogen load and irradiance on photosynthetic pigment concentrations in Cladophora vagabunda and Gracilaria tikvahiae in estuaries of Waquoit Bay. Biol Bull 199: 223225.

Edwards P 1970. Illustrated guide to the seaweeds and seagrass in the vicinity of Porto Aransas, Texas. Contrib Mar Sc Austin 15: 1-228.

Ferreira LB, Barufi JB, Plastino EM 2006. Growth of red and green strains of the tropical agarophyte Gracilaria cornea J. Agardh (Gracilariales, Rhodophyta) in laboratory. Rev Bras Bot 29: 187-192.

Frank H, Das SK, Bautista S, Bruce D, Vasil'ev S, Crimi M, Croce R, Bassi R 2001. Photochemical behaviour of xanthophylls in the recombinant photosystem II antena complex, CP26. Phytochemistry 40: 1220-1225.

Godillo FJ, Aguilera J, Jiménez C 2006. The response of nutrient assimilation and biochemical composition of Artic seaweeds to a nutrient input in summer. $J$ Exp Bot 57: 2661-2671.

Gressler V, Yokoya NS, Fujii MT, Colepicolo P, Mancini Filho J,Torres RP, Pinto E 2010. Lipid, fatty acid, protein, amino acid and ash contents in four Brazilian red algae species. Food Chem 120: 585-90.

Guimarães M, Plastino EM, Oliveira EC 1999. Life-history, reproduction, and growth of Gracilaria domingensis (Gracilariales, Rhodophyta) from Brazil. Bot Mar 42: 481-486

Guimarães M, Plastino EM, Destombe C 2003. Green mutant frequency in natural populations of Gracilaria domingensis (Gracilariales, Rhodophyta) from Brazil. Eur J Phycol 38: 165-169.

Hulshof PJM, Kosmeijer-Schuil T, West CE, Hollman PCH 2007. Quick screening of maize kernels for provitamin A content. J Food Comp Anal 20: 655-661.

Jeffrey SW, Humphrey GF 1975. New spectrophotometric equations for determining chlorophylls a, b, c1 e c2 in higher plants, algae and natural phytoplankton. Biochem Physiol Pfl 167: 191-194.

Jones AB, Dennison WC, Stewart GR 1996. Macroalgal responses to nitrogen source and availability: amino acid metabolic profiling as a bioindicator using Gracilaria edulis (Rhodophyta). J Phycol 52: 757-766.

Kakita H, Kamishima H 2006. Effects of environmental factors and metal ions on growth of the red alga Gracilaria chorda Holmes (Gracilariales, Rhodophyta). J Appl Phycol 18: 469-474.

Kosovel V, Talarico L 1979. Seasonal variation of photosynthetic pigments in Gracilaria verrucosa (Huds.) Papenfuss (Florideophyceae, Gigartinales). B Soc Adriat Scien 63: 5-15.

Kuhnen S, Lemos PMM, Campestrini LH, Ogliari JB, Dias PF, Maraschin M 2009. Antiangiogenic properties of carotenoids: a potential role of maize as functional food. J Funct Foods 1: 284-290.

Kursar TA, van der Meer J, Alberte RS 1983. Light-harvesting system of red alga Gracilaria tikvahiae. I. Biochemical analyses of pigment mutations. Plant Physiol 73: 353360.

Lapointe BE 1981. The effects of light and nitrogen on growth, pigment content, and biochemical composition of Gracilaria foliifera v. angustissima (Gigartinales, Rhodophyta). J Phycol 17: 90-95.

Plastino EM, Guimarães M, Matioli SR, Oliveira EC 1999. Codominant inheritance of polymorphic color variants of Gracilaria domingensis (Gracilariales, Rhodophyta). Gen Mol Biol 22: 105-108.

Scott, CE, Eldridge, AL 2005. Comparison of carotenoid content in fresh, frozen and canned corn. J Food Comp Anal 18: 551-559.

Talarico L, Maranzana G 2000. Light and adaptive responses in red macroalgae: an overview. J Photoch Photobiol B 56: $1-11$.

Ursi S, Plastino EM 2001. Growth of reddish and light green strains of Gracilaria sp. (Gracilariales, Rhodophyta) in two culture media: analysis of different reproductive phases. Rev Bras Bot 24: 587-594.

Wilson AJ, Critchley AT 1997. Studies on Gracilaria gracilis (Stackhouse) Steentoft, Farnham and Irvine and Gracilaria aculeata (Hering) Papenfuss from southern Africa. I. The influence of temperature, irradiance, salinity and nitrogen-nutrition on growth. $S$ Afr J Bot 63: 465-473

Zar JH 1999. Biostatistical analysis. New Jersey: Prentice Hall.

Zou D, Gao K 2009. Effects of elevated $\mathrm{CO}_{2}$ on the red seaweed Gracilaria lemaneiformis (Gigartinales, Rhodophyta) grown at different irradiance levels. Phycologia 48: 510517.

\section{*Correspondence}

Nair S. Yokoya

Núcleo de Pesquisa em Ficologia, Instituto de Botânica

Caixa Postal 3005, 01031-970 São Paulo-SP, Brazil

nyokoya@pq.cnpq.br

Tel.: +551150676121 